University of Wollongong

Research Online

Faculty of Law, Humanities and the Arts Papers (Archive)

Faculty of Arts, Social Sciences \& Humanities

$1-1-2014$

Extensive food adulteration in Bangladesh: a violation of fundamental human rights and the state's binding obligations

S M. Solaiman

University of Wollongong, sheikh@uow.edu.au

Abu Noman Mohammad Atahar Ali

University of Wollongong, anmaa@uow.edu.au

Follow this and additional works at: https://ro.uow.edu.au/lhapapers

Part of the Arts and Humanities Commons, and the Law Commons

Research Online is the open access institutional repository for the University of Wollongong. For further information contact the UOW Library: research-pubs@uow.edu.au 


\title{
Extensive food adulteration in Bangladesh: a violation of fundamental human rights and the state's binding obligations
}

\begin{abstract}
(C) The Author(s) 2014. The right to life is inherently connected with the right to food which implies that any foodstuff be nutritious and safe. The government of Bangladesh bears binding obligations to protect these rights under both international human rights instruments and its national constitution. The violation of these rights has, nonetheless, been commonplace causing numerous human deaths and terminal diseases. The perpetrators have been adulterating foods, flouting laws with impunity and taking advantage of regulatory impotence and governmental lenience for decades. Laws exist in books, regulators subsist in theory, but consumers die without remedies. This situation must not prevail forever as every human has an inherent right to live until their natural demise. This article aims to explore the binding obligations of the government to prevent food adulteration and to protect people's essential rights. It highlights that numerous laws exist almost invisibly in the country, and recommends that their enforcement be reinforced in order to protect the people who are exposed to the overly contaminated food markets in Bangladesh.
\end{abstract}

\section{Keywords}

rights, human, fundamental, violation, bangladesh, binding, state, food, obligations, adulteration, extensive

\section{Disciplines}

Arts and Humanities | Law

\section{Publication Details}

S. M. Solaiman \& A. N. Ali, 'Extensive food adulteration in Bangladesh: a violation of fundamental human rights and the state's binding obligations' (2014) 49 (5) Journal of Asian and African Studies 617-629. 


\title{
EXTENSIVE FOOD ADULTERATION IN BANGLADESH: A VIOLATION OF FUNDAMENTAL HUMAN RIGHTS AND STATE'S BINDING OBLIGATIONS
}

\author{
S M Solaiman* \\ Abu Noman Mohammad Atahar Ali*
}

\begin{abstract}
The right to life is inherently connected with the right to food which implies that any foodstuff be nutritious and safe. The Government of Bangladesh bears binding obligations to protect these rights under both international human rights instruments and its national Constitution. The violation of these rights has, nonetheless, been commonplace causing numerous human deaths and terminal diseases. The perpetrators have been adulterating foods flouting laws with impunity taking advantage of regulatory impotence and governmental lenience for decades. Laws exist in books, regulators subsist in theory, but consumers die without remedies. This situation must not prevail forever as every human has an inherent right to live until his/her natural demise. This article aims to explore the binding obligations of the government to prevent food adulteration and to protect people's essential rights. It highlights that numerous laws exist almost invisibly in the country, and recommends that their enforcement be reinforced in order to protect the people who are exposed to the overly contaminated food markets in Bangladesh.
\end{abstract}

\section{INTRODUCTION}

Food safety has been a crucial global concern for public health for the last decade. Recurrent incidents of food contamination around the world have made food safety an increasingly international distress that has prompted the World Health Organization (WHO) to recognize 'foodborne diseases as a global public health challenge' ${ }^{1}$ The United Nations (UN) finds that this concern may be particularly significant for a developing country where, at any given time, about one-half of its total population suffer from various diseases caused by unsafe water or adulterated foods. ${ }^{2}$ Children in South Asian countries including Bangladesh are the worst-hit victims of under-nutritious foods. ${ }^{3}$ 
Food is a critical need of all to survive. An essential life-saver may, however, become dreadful when it turns into a 'silent killer'. This has been the case in Bangladesh where almost all such as food manufacturers, ${ }^{4}$ restaurants, ${ }^{5}$ institutional cafeterias, ${ }^{6}$ and fast food retailers $^{7}$ are involved in adulteration in one way or another. Even home-cooked dishes are largely contaminated by pesticide-laden produce, ${ }^{8}$ adulterated oil and spices, ${ }^{9}$ and other impure food ingredients. ${ }^{10}$ A joint study released in November 2013, carried out by the representatives of the Harvard School of Public Health (HSPH), the Boston Children's Hospital and the Dhaka Community Hospital, has found excessive levels of toxic metal in turmeric powders of different brands to be "primarily responsible for lead contamination in the blood of 284 children' (discussed in some detail below). ${ }^{11}$ The US Government banned PRAN's turmeric powder in October 2013, when the US Food and Drug Administration detected its high level of lead. ${ }^{12}$ Perhaps most alarming are the serious allegations against the so-called purified water supplied to different places, including hospitals across the country, that 'these are germ-infested' liquids. ${ }^{13}$ Indeed shockingly, even medicine too is reportedly tainted. ${ }^{14}$ In view of such reality, it seems, the entire food industry in Bangladesh has lost its integrity by offering unsafe foods to consumers, sometimes naively, and mostly culpably.

The Government of Bangladesh (GOB), aware of this endemic problem, has enacted laws to combat its onslaught, with little success to date. Governmental failures are multifaceted. Notably, the GOB has largely failed to draft useful laws, has manifestly failed to enforce the existing laws, and regulators have utterly failed to detect and penalize egregious conduct of scrupulous businesses. These failures are echoed in Jean Ziegler's report as the UN Special Rapporteur on the right to food in Bangladesh, which notes that although several pieces of fragmented legislation are in place, they do not 'fully reflect international standards' and their enforcement seems ineffective. ${ }^{15}$ Pointing to the harms caused by unsafe foods, Negri claims it as a common view that "protecting world health from foodborne illnesses and similar 
hazards is to be seen as a compelling duty and a primary interest of both States and non-State actors. $^{16}$

This article aims to explore the recognition and violations of the people's right to food and right to life, and the impacts of these on the public in Bangladesh. It shows the extent of adulteration and harms caused by unsafe foods that exemplify the state's failure to protect these fundamental human rights, in breach of its international and constitutional obligations. It demonstrates that dishonest businesses have been randomly adulterating foods and selling them to consumers with impunity for decades. Conclusions submit that, in order to discharge its binding obligations, the GOB needs to be proactive in protecting the people and preventing the culpability of businesses by strengthening the enforcement of, and compliance with, the law.

FOOD ADULTERATION AND ITS DEADLY EFFECTS ON THE PEOPLE IN

\section{BANGLADESH}

Foods are adulterated in three main ways in Bangladesh. Firstly, the wrongdoers use various harmful chemicals, such as pesticide, formalin, and toxic colors, to keep foods fresh and make them attractive. ${ }^{17}$ Secondly, they store, sell and serve to consumers rotten perishables turned poisonous foods in an unhygienic atmosphere. ${ }^{18}$ Thirdly, people in Bangladesh are fond of spices; taking advantage of this fondness, manufacturers mix toxic substances such as husks with different spices and edible oils. ${ }^{19}$

Different studies carried out over the past two decades reveal the terrible effects of contaminated foods on residents in Bangladesh. A 1984 study conducted by the Institute of Nutrition and Food Science, Dhaka University, discovered that inadequate diet and consumption of adulterated foods were responsible for the malnutrition of $60 \%$ of the country's population. ${ }^{20}$ A 1994 joint study on food safety by the Institute of Public Health 
(IPH) in Dhaka and the WHO tested 52 items of street food vendors and discovered that all of the tested samples were contaminated with germs of different types of diseases. ${ }^{21}$ These two organizations conducted another joint study in 2003 in Dhaka that revealed $96 \%$ of sweetmeats, $24 \%$ of biscuits, $54 \%$ of breads, and $59 \%$ of ice creams of the tested samples were adulterated. $^{22}$

Unsafe foods significantly contribute to malnutrition, which permanently handicaps people, retards mental and physical development, affects development of brain cells, and causes blindness and other diseases. ${ }^{23}$ The UN Food and Agriculture Organization (FAO) has recently found that malnutrition rates in Bangladesh are amongst the highest in the world. ${ }^{24}$

Further, a WHO report provides that contaminated foodstuffs cause premature deaths of at least three million children under five years of age worldwide. ${ }^{25}$ The WHO foretells that more than two-thirds of the world's 60-year-old population will live in developing countries by 2025 , and they are likely to be exposed to the increased risk of food-borne diseases. ${ }^{26}$ Consistently, the United Nations Children's Emergency Funds (UNICEF) identifies that the people in South Asia are greatly exposed to the risks associated with food safety and under nutrition. $^{27}$

Bangladesh is seriously vulnerable to food-borne diseases; many people die from consuming toxic foods every year. ${ }^{28}$ Taking into account the extent of harms inflicted by such foodstuffs, local experts claim that 'food adulteration is like silent genocide'. ${ }^{29}$ Recent official statistics of the Ministry of Health and Family Welfare (MHFA) mirror the serious threat posed by unsafe foods in Bangladesh. The MHFA statistics reproduced below provide specific details of the number of food samples tested by the IPH during from 2001 to 2009 , showing on a yearly basis the distribution of genuine and adulterated samples out of the total samples tested. $^{30}$ 
Table 1: Food Samples Tested from 2001 to 2009 by IPH

\begin{tabular}{|l|l|l|l|l|l|}
\hline \multirow{2}{*}{ Year } & Total & \multicolumn{2}{|l|}{ Genuine } & \multicolumn{2}{l|}{ Adulterated } \\
\cline { 3 - 6 } & Samples & No. & $\%$ & No. & $\%$ \\
\hline 2001 & 3280 & 1692 & $51.6 \%$ & 1588 & $48.4 \%$ \\
\hline 2002 & 4300 & 2110 & $49.0 \%$ & 2190 & $51.0 \%$ \\
\hline 2003 & 5120 & 2515 & $49.1 \%$ & 2605 & $50.9 \%$ \\
\hline 2004 & 4413 & 2214 & $52.0 \%$ & 2119 & $48.0 \%$ \\
\hline 2005 & 6337 & 3200 & $50.5 \%$ & 3137 & $49.5 \%$ \\
\hline 2006 & 2779 & 1405 & $50.6 \%$ & 1374 & $49.4 \%$ \\
\hline 2007 & 5992 & 3488 & $58.2 \%$ & 2504 & $41.8 \%$ \\
\hline 2008 & 8734 & 5066 & $58.0 \%$ & 3668 & $42.0 \%$ \\
\hline 2009 & 6338 & 3356 & $52.9 \%$ & 2982 & $47.1 \%$ \\
\hline
\end{tabular}

Source: MHFA

Table 1 displays the prevalence of unsafe foods, with no sign of improvement over the decade. Given the seriousness of the situation, the GOB in 2004 had appointed the National Taskforce on Food Safety (NTFS) to specifically identify the causes and consequences of unsafe foods in the country. The NTFS's survey reaffirms the continued existence of harms caused by contaminated foods, including malnutrition and diseases leading to the death of many people every year. ${ }^{31}$ More specifically, the NTFS identifies that diarrhoeal diseases resulting from consumption of perilous foods cause various disabilities of 5.7 million people each year, ${ }^{32}$ while a total of 1657381 cases of acute diarrhoea result in 2064 deaths occurred in 1998 alone. $^{33}$

Attacks and deaths from diarrhoea seem to have reached their peak over recent years. This is evident from the report of the Director General of Health Services in Bangladesh (DGHS), which epitomizes the magnitude of the diarrhoeal diseases, and confirms that poisonous 
foods have been the main cause of this serious health hazard. Table 2 depicts the incidents of attacks and deaths caused by diarrhoeal diseases from 2003 to $2009 .{ }^{34}$

Table 2: Year-wise Reported Diarrhoea Attacks and Deaths in Bangladesh

\begin{tabular}{|l|l|l|l|l|l|l|l|}
\hline Year & 2003 & 2004 & 2005 & 2006 & 2007 & 2008 & 2009 \\
\hline $\begin{array}{l}\text { Number of } \\
\text { Attacks }\end{array}$ & 2196919 & 2132434 & 2040927 & 1961850 & 2335326 & 2294979 & 5036849 \\
\hline $\begin{array}{l}\text { Number of } \\
\text { Deaths }\end{array}$ & 1032 & 1067 & 694 & 239 & 537 & 393 & 712 \\
\hline
\end{tabular}

The situation seems to be improving: the number of deaths in 2009 is lower than in 2003. However, two points should be made here. Firstly, the Table shows that the lowest deaths occurred in 2006; since then casualties recorded an upward trend. Secondly, the number of attacks in 2003 was 2196919, which reached an alarming 5036849 in 2009. The relative reduction in deaths, however, should be largely attributed to improved medical services under the auspices of various national and international efforts, rather than to any purification of foods. This claim of continued lack of purity is clearly evidenced by the rapid increase in numbers of attacks. The number of deaths itself is, nevertheless, still appalling.

The 2013 study following the presence of lead in children's blood has discovered lead in turmeric powders. ${ }^{35}$ The research team randomly collected 18 samples of turmeric powders of diverse brands from different households in Sirajdikhan of Munshiganj district. The samples, tested at a laboratory of the HSPH, all contained lead, 12 samples contained excessive levels, up to $483 \mathrm{ppm}$, well above the permitted limit of $2.5 \mathrm{ppm}$ set forth by the Bangladesh Standards and Testing Institution. ${ }^{36}$ The 2013 study followed an inquiry into the finding of a high level of lead in the blood of $80 \%$ of the children aged between 20 and 40 months in Sirajdikhan. ${ }^{37}$ They undertook the research to ascertain whether the child's health 
had been affected by the presence of any metal in the mother's body. Maitreyi, the team leader, says '[c]hildren with lead in blood do worst in schools and they cannot reverse that because it damages their brains permanently'. ${ }^{38}$ The study indicates more detrimental effects of lead, such as heart and kidney problems, and even death. ${ }^{39}$

This problem, a wilful creation of humans, is an upshot of the legal and regulatory failures ${ }^{40}$ to combat the cupidity of businesses against the gullibility of consumers. The discussion below demonstrates that the right to safe food is part of the internationally recognized human rights and constitutionally established fundamental rights.

\section{HUMAN RIGHTS AND FUNDAMENTAL RIGHTS}

All human rights are interrelated, interdependent and indivisible. Therefore, the enjoyment of one right may necessitate access to other entitlements. For example, the enjoyment of the right to life entails, amongst other things, the consumption of safe foods. Right to health and right to safe food are thus intrinsically combined in the right to life as a human right.

International human rights and fundamental rights are generally distinguished by reference to their incorporation in a national constitution and in a piece of implementing/enabling legislation. ${ }^{41}$ Fundamental rights are explicitly or by necessary implication embodied in, and guaranteed by, the national constitution; they require 'a high degree of protection from government encroachment,' as recognized by the US Supreme Court (USSC). ${ }^{42}$ These rights are often called 'fundamental constitutional rights'. ${ }^{43}$ The Constitution of Bangladesh (Constitution) has adopted many of these international human rights as 'fundamental rights' (arts 26 - 44). Highlighting the importance of fundamental rights, the USSC in Palko v State of Connecticut held that 'neither liberty nor justice would exist if they were sacrificed. ${ }^{44}$

The most distinctive feature of fundamental rights is perhaps their inviolability, evident from the pronouncement more than a century ago of the USSC in Boyd and Others $v$ United States 
that, '[i]t is the duty of courts to be watchful for the constitutional rights of the citizen, and against any stealthy encroachments thereon'. ${ }^{45}$ The Supreme Court of Bangladesh (SCB) has echoed this view on several occasions. Asserting the responsibility of the state, the SCB pronounced in Ain O Salish Kendra (ASK) v Government of Bangladesh that, the state has a constitutional obligation to make effective provisions for securing the right to life, living and livelihood within its economic capacity. ${ }^{46}$ Declaring its own duty the SCB held in State v Deputy Commissioner Satkhira that, the Court has a constitutional responsibility to ensure that the people's fundamental rights are preserved and well protected. ${ }^{47}$

Human rights treaties confer rights directly on individuals, and such a treaty thus binds a state party to both its own nationals and other parties to the instrument under the principle of pacta sunt servanda. ${ }^{48}$ The set of norms and obligations laid down by international human rights law is enforceable against a member state to protect rights of its citizens as human rights. ${ }^{49}$

Regarding the right to food, the UN Office of the High Commissioner for Human Rights (OHCHR) observes that domestic courts are increasingly hearing allegations against violations of this right as the ultimate guarantor of human rights. ${ }^{50}$ In relation to the enforcement of international human rights, the Supreme Court of India (SCI) played a proactive role, holding in Vishaka $v$ State of Rajasthan that international norms were to be read into fundamental rights even if this is not particularly transformed into domestic law. ${ }^{51}$ The High Court of Australia took a similar approach to international human rights in Minister of State for Immigration and Ethnic Affairs $v$ Teoh. ${ }^{52}$ This is especially pertinent to the present research in that, although Bangladesh is a party to the International Covenant on Economic, Social and Cultural Rights (ICESCR), which directly confers the right to food upon the people, it has not enacted any enabling legislation giving this crucial covenant the force of law. ${ }^{53}$ 
Therefore, a state which incorporates certain rights in its constitution and ratifies an international convention containing those rights assumes binding obligations under both the national and international instruments.

\section{THE INTERRELATIONSHIP BETWEEN THE RIGHT TO LIFE AND THE RIGHT} TO FOOD

Menghistu comments that ' $[\mathrm{t}]$ he right to life is the most basic, the most fundamental, the most primordial and supreme right which human beings are entitled to have and without which the protection of all other human rights becomes either meaningless or less effective. ${ }^{54}$ It is now widely accepted that the right to consume 'safe food' is an essential right in modern civilisation. ${ }^{55}$ Defining the right to food, the OHCHR observes that '[i]t is not simply a right to a minimum ration of calories, proteins and other specific nutrients. It is a right to all nutritional elements that a person needs to live a healthy and active life, and to the means to access them.' ${ }^{56}$ Affirming their indivisibility, the OHCHR provides that violations of the right to food may hinder the enjoyment of other human rights such as right to life and right to health. ${ }^{57}$ It further clarifies that the right to safe food is inherent in the broader right to food which requires the food to be adequate, safe and accessible. ${ }^{58}$ The United Nations General Assembly (UNGA) in April 2013 reaffirmed the interplay between this right to life and right to safe food. ${ }^{59}$ Negri explains the emergence of the right to safe food as an autonomous human right derived from the rights to food and to health, noting that these rights are closely interrelated. ${ }^{60}$

As the above discussion shows, both the right to life and right to food are naturally combined and regarded as fundamental human rights. The right to safe food in this article is considered mainly as part of the right to life and right to food that are enshrined as human rights in 
various international instruments and that are incorporated as fundamental rights in the Constitution. The following discussion begins with the general concepts of these rights.

\section{GENERAL CONCEPTS OF THE RIGHT TO LIFE AND RIGHT TO FOOD}

The contemporary broad concept of protection of the right to life includes providing basic needs such as food, medical care and access to health facilities. ${ }^{61}$ The United Nations Human Rights Committee (UNHRC) requires member states to take positive steps to protect even the environment in order to protect the right to life. ${ }^{62}$ Thus, life essentially requires food.

The modern construction of the right to food has been extended to incorporate safe food in order to ensure sound health and active life. ${ }^{63}$ Food adulteration which vitiates the quality of foodstuffs through adding inferior substance destroys or diminishes the nutritional value of foods, contributing to malnutrition of consumers. ${ }^{64}$ Malnutrition causes serious harms. ${ }^{65}$

Such a finding underscores the significance of safe foods, and justifies the claim that the right to food is one of the most important entitlements amongst all economic, social and cultural rights. ${ }^{66}$ Simply, any food is for a life to live, and if the substance is unsafe for humans, it cannot be human food in any true definition of food. The right to life and right to food are internationally recognized as follows.

\section{RECOGNITION OF THE RIGHT TO LIFE AND RIGHT TO FOOD AS INTERNATIONAL HUMAN RIGHTS}

Several international instruments acknowledge the right to life as an inherent right of every human being. Two of the most important of those instruments that directly incorporate the right to life are the Universal Declaration of Human Rights (UDHR) and the International Covenant on Civil and Political Rights (ICCPR). Article 3 of the UDHR lays down the right to life of every person, whilst art 6(1) of the ICCPR provides legal protection to this right as 
an inherent right of all human beings. The UDHR, which has strong persuasive effects on states, embraces the right to an adequate standard of life including the right to life and right to food. ${ }^{67}$

The right to food is an acknowledged entitlement of everyone. Article 25 of the UDHR encompasses this right, which is enshrined in art 11 of the ICESCR, with a binding effect on the state parties. Pursuant to art 11.1 of the ICESCR, state parties have recognised 'the right of everyone to an adequate standard of living including ... adequate food', and thereby have assumed responsibility to 'take appropriate steps to ensure the realization of this right'. Article 11.2 contains further recognition of the state parties that urgent steps may be needed to ensure 'the fundamental right to freedom from hunger and malnutrition.' General Comment 12 of the Committee on Economic, Social and Cultural Rights (CESCR), aimed at identifying and clarifying important issues in relation to the right to adequate food, proffers the meaning of the requirements of this right for its realization. ${ }^{68}$ According to the CESCR, this human right 'is of crucial importance for the enjoyment of all rights', ${ }^{69}$ and it 'affirms that the right to adequate food is indivisibly linked to the inherent dignity of the human person and is indispensable for the fulfilment of other human rights enshrined in the International Bill of Human Rights. ${ }^{70}$ The CESCR further emphasizes that this right requires food to be safe, ${ }^{71}$ and free from adverse substance. ${ }^{72}$ Explaining the nature of state obligation, the CESCR notes that '[e]very State is obliged to ensure for everyone under its jurisdiction access to the minimum essential food which is sufficient, nutritionally adequate and safe ....' 73 The phrase 'adequate food', as contained in the UDHR and the ICESCR, has been clarified by the OHCHR, which provides that 'adequacy' refers to the food that must satisfy 'dietary needs' having regard to age, living conditions, health etc. ${ }^{74}$ It further provides that food should be safe for human consumption and free from all sorts of contaminants. ${ }^{75}$ 
Therefore, both the CESCR and the OHCHR put distinct emphasis on safe foods concerning the right to food. This view is also supported by the UNGA.

UNGA Resolutions 51/171 and 57/226 affirm that everyone has the right to access safe and nutritious food, consistent with the right to adequate food. ${ }^{76}$ The UN Human Rights Council (HRC) in 2008 reaffirmed all the previous resolutions of different UN bodies regarding the right to food. ${ }^{77}$

The foregoing discussion justifies the claim that offering unsafe foods to people is denial of both their right to life and right to food, as the latter is considered an essential component of the former. A state is obliged to implement its commitments and undertakings embodied in an international accord which records its consent. With respect to the realization of the right to safe food, Ziegler (as a UN Special Rapporteur) highlights that the commitment of Bangladesh to human rights should be taken into account in any analysis of the right to food, ${ }^{78}$ which is discussed below.

\section{STATE OBLIGATIONS UNDER INTERNATIONAL HUMAN RIGHTS} INSTRUMENTS

Bangladesh, as a member of the UN and party to major international instruments including the ICESCR and ICCPR, has assumed obligation to ensure food safety in the country. It ratified particularly the ICESCR on October 5, 1998 and the ICCPR on September 6, 2000. In view of such ratifications, Ziegler and others point out that 'Bangladesh has committed itself to respect, protect and fulfil the right to food, without any discrimination' ${ }^{79}$

Ziegler in his report as Rapporteur indicated that any specific breaches of obligations of Bangladesh under the aforesaid international instruments should be treated as violations of human rights. ${ }^{80}$ The OHCHR asserts that the state is obligated to ensure that none of its institutions or any third parties violate its people's right to safe food, and it should take 
necessary measures to ensure their enjoyment of this right. ${ }^{81}$ The OHCHR supplements that the state 'obligation to protect also includes ensuring that food put on the market is safe and nutritious. States must therefore establish and enforce food quality and safety standards.... ${ }^{82}$ Complementing the OHCHR, the CESCR regarding the rights contained in the ICESCR emphasizes that every state party has an obligation to ensure the satisfaction of each right at least at the minimum level. ${ }^{83}$ Underpinning these obligations, the OHCHR appropriately mentions that Bangladesh must be proactive in strengthening access to an adequate standard of life and safe food. ${ }^{84}$

Bangladesh has therefore assumed obligations to protect the right to life and right to safe food under international law. In addition, the GOB is constitutionally obliged to ensure food safety as part of fundamental rights, as explained below.

\section{PEOPLE'S FUNDAMENTAL RIGHTS AND THE STATE'S CONSTITUTIONAL OBLIGATIONS}

The Constitution imposes binding obligations on the state to protect both the right to life and right to food for everyone in the country. Article 32 provides that no person shall be deprived of life except in accordance with law. On a food safety writ petition, the SCB held that the right to life under art 32 includes everything needed to make it meaningful and a life worth living: such as, 'the maintenance of health is of utmost importance' and it inevitably requires safe food. ${ }^{85}$ Complementary to art 32 , art 31 stipulates that every person in Bangladesh has an inalienable right to enjoy the protection of law as well as to be treated in accordance with law. Article 31 further dictates that no action detrimental to the life or body of any person shall be taken, except in accordance with law. The SCB, in interpreting art 31 in Gias Uddin v Dhaka Municipal Corporation, held that the protection of life means that one's life cannot 
be imperilled by any action beyond the scope of, or contrary to, law. ${ }^{86}$ As shown earlier, adulterated foods do imperil human life.

Although the right to food is not explicitly included as a fundamental right in the Constitution, the articulation and judicial interpretations of arts 32 and 31 recognize the existence of this right. For example, the SCB in Nurul Islam v Government of Bangladesh pronounced that the right to life under art 31 means the right to have a sound mind and health, ${ }^{87}$ whilst safe foods are a critical need of sound health. ${ }^{88}$ Further, the obligations under fundamental rights are supplemented by the 'fundamental principles of state policy' embodied in the Constitution (arts 8-25). Article 15 provides:

It shall be a fundamental responsibility of the State to attain, through planned economic growth, a constant increase of productive forces and a steady improvement in the material and cultural standard of living of the people, with a view to securing to its citizens (a) the provision of the basic necessities of life, including food, ... and medical care.

It is pertinent to mention that, unlike fundamental rights, the fundamental principles of state policy do not explicitly impose binding obligations upon the state, which nonetheless has a constitutional obligation to enforce art $15(\mathrm{a})$, as can be inferred from the judicial interpretation of another fundamental state policy contained in art 18(1), which reads:

The State shall regard the raising of the level of nutrition and the improvement of public health as moving its primary duties, and in particular shall adopt effective measures to prevent the consumption ... of ... intoxicating drinks and drugs which are injurious to health.

The SCB applied and interpreted art 18(1) with respect to food safety in Farooque $v$ Government of Bangladesh, ${ }^{89}$ which involved the importation of radioactively contaminated milk powder to Bangladesh. The petitioner claimed that the toxic milk powder was imported in violation of the right to life guaranteed and protected respectively under aforementioned arts 32 and 31 . He cited art 18(1) on the ground of public health to secure his claim. The Court accepted the infringement of the constitutional right to life and right to food by the respondent's importation of adulterated foods in Bangladesh, and held that: 
[T] hough article 18 cannot be enforced by the Court, it can be ... [consulted for] interpreting the meaning of the right to life under Articles 31 and 32. A man has a natural right to the enjoyment of healthy life and longevity up to normal expectation of life in an ordinary human being. Enjoyment of a healthy life and normal expectation of longevity is threatened ... when a man consumes food, drink, etc, injurious to health, he suffers ailments and his life and normal expectation of longevity are threatened. The natural right of man to live free from all the man made hazards of life has been guaranteed under the aforesaid Articles 31 and 32 ... [emphasis added]..$^{90}$

It is thus judicially established that the state bears constitutional obligations to protect people's right to life and right to safe food and that food adulteration and the supply of adulterated foodstuffs for human consumption are contrary to these rights. Notably, the state also has an international obligation to implement both arts 15(a) and 18(1) because they are related to the right to life and right to food, as alluded to earlier. When markets are inundated with adulterated foods, consumers' rights will inevitably be subject to violation.

\section{VIOLATIONS OF PEOPLE'S RIGHTS AND RESPONSIBILITIES OF THE GOVERNMENT}

Violations do not necessarily mean positive action. Pogge comments, '[h] uman rights violations involve both the nonfulfillment of a human right and a certain causal responsibility of human agents for this non-fulfillment' and adds that '[a] particular human right of some particular person is unfulfilled when this person lacks secure access to the object of that human right. ${ }^{91}$ Corresponding to the pronouncement of the SCB discussed above that a violation of the right to food in effect violates the right to life, the SCI upheld an identical view on these rights in People's Union for Civil Liberties v Union of India. ${ }^{92}$

Such facts of casualties of unsafe foods in Bangladesh evidently reveal the state's failures to discharge its obligations triggering violations of its people's rights. A state party is prima facie responsible for breach of its obligations under the ICESCR where any significant number of its people are deprived of their right to safe food. ${ }^{93}$ The HRC affirms that the ultimate obligations to respect, protect and fulfil human rights virtually lie with the 
government, ${ }^{94}$ and an identical view is echoed by the OHCHR. ${ }^{95}$ Hence, the GOB should accept its responsibility for violations of people's rights in the country.

Arguably, violations of these rights can be attributed to an obvious lack of governmental commitment to protect the public and punish the culprits. This is because successive governments had until 2009 been ignoring the need for protection of these rights. The incumbent, government amid public demands, creditably enacted new legislation titled the Consumer Protection Act 2009, aiming at updating multiple old laws governing this area. The drawbacks of the 2009 legislation and its resultant failure, however, became apparent even before its enforcement, prompting the government to enact yet another piece of legislation called the Safe Foods Act 2013 in October 2013. Currently numerous laws are in books, though almost none of them are being strictly enforced, which makes the law practically redundant. Although the current legal framework suffers from various flaws, ${ }^{96}$ the main problem lies in the lack of sincerity of the GOB, perhaps best manifested in its failure to implement the 2009 directions of the SCB to set up food courts.

A non-governmental organization, amidst growing public concerns over the abundance of adulterated foods in markets, lodged a public interest litigation with the SCB in June 2009. The petitioner sought and got directives of the Court on the GOB in order to ensure food safety in the country. The Court directed the GOB to establish a Food Court in each division and district city across the country, and to appoint adequate number of 'Public Analyst of Food,' as required under s41 and s4 respectively of the Pure Food Ordinance 1959, within two years of receiving the copy of the judgment. ${ }^{97}$ In response, although an inadequate number of food analysts and inspectors have been appointed, virtually no court has been established to date. ${ }^{98}$ Consequently, the GOB faced a 'contempt rule' in December 2012, 
owing to its not submitting a progress report by July 1, 2011 on its actions towards consumer protection following those directives. ${ }^{99}$

Despite the flaws in laws, the incumbent GOB appreciably enacted these two pieces of legislation - one in the first year, the other in the last month of its five-year term (October 2013). The outgoing Food Minister says, just after enacting the second piece, that ' $[\mathrm{t}]$ here are lots of laws in the country which are not implemented properly. We should give emphasis on [sic] reinforcing it properly; otherwise the people will not get any results from the enacted laws. ${ }^{100}$ This late realization is welcome, even though without any plan for implementation of laws. However, as solicited elsewhere, the enforcement mechanisms could be reorganized along the lines of the responsive regulation theory, which could arguably help achieve effective regulation of food safety in Bangladesh. ${ }^{101}$

To wrap up, the above discussions demonstrate governmental failures to discharge its obligations and resultant violations of people's critical rights. Simply, laws exist in books, regulators subsist in theory, but consumers die without remedies. This situation cannot and should not persist forever. Time is ripe to impel the GOB to foster the enforcement of existing laws to address the dire need of human protection. Efforts should, however, continue to close the legal loopholes to hook up the crooks.

\section{CONCLUSIONS}

Food safety is equally crucial for every human being regardless of nationality or financial ability. This issue is even more daunting in developing and least-developed countries than in their developed counterparts in that, unlike the case in the latter, a vast majority of people in the former are unable to pay for their medicare. The GOB bears both international and constitutional obligations to ensure food safety in the country. Governmental failures to discharge its obligations have caused violations of fundamental human rights, with 
irreversible human loss. Such failures and resultant casualties have, nonetheless, become commonplace in Bangladesh. All these are happening, unfortunately, with almost complete impunity. The GOB will have to accept its failure to prevent harm to its people, in breach of its mandatory duties. Half-hearted cosmetic legal reforms are bound to be futile; an immediate whole-hearted action against the endemic adulteration by enforcing the existing laws and making useful regulatory reforms is long overdue. It cannot be gainsaid that the malefactors are taking advantage of the regulatory impotence. The existing legal norms do somehow capture several, though not all, aspects of food adulteration. ${ }^{102}$ Any future reforms must emphasize enforcement of existing sanctions, rather than further expanding the list of prohibitions. This is so because no normative threat can inflict any real caveat on potential offenders when their impunity is taken for granted. It is to be borne in mind that every human life has an inherent right to live until its natural demise.

* Authors are with the School of Law, University of Wollongong, Australia. They wish to express their sincere gratitude to two anonymous reviewers for their constructive and helpful comments.

${ }^{1}$ S. Negri, "Food safety and global health: an international law perspective," Global Health Governance 3/1 (2009), p. 1.

2 P. H. Gleick, "The human right to water," Water Policy 1 (1998) p. 488.

${ }^{3}$ See P. F. and D. Maru, "Human rights and health systems development: Confronting the politics of exclusion and the economics of inequality," Health and Human Rights: An International Journal 14 (2012), p. 2.

${ }^{4}$ See, eg, "Substandard vermicelli factory found in city," Daily Star, Dhaka, September 19, 2005, Front Page.

${ }^{5}$ See, eg, S. A. Khan, "Adulterated foods on sale in city amid lax monitoring," New Age, Dhaka, May 27, 2009, Front Page.

${ }^{6}$ See, eg, I. Hasan, "Move to maintain food quality in DU canteens," Daily Star, Dhaka, September 18, 2005, Star City.

${ }^{7}$ See, eg, "2 fast food shops fined," Daily Star, Dhaka, February 24, 2010, National.

${ }^{8}$ M. A. Khan, "Bitter Truth - pesticide-laced food serious health risk," Daily Star, Dhaka, August 24, 2013, Op-Ed.

${ }^{9}$ See, "PRAN turmeric banned in US, selling on local market," Daily Sun, Dhaka, October 23, 2013, First Page.

${ }^{10}$ See, Anisur Rahman, 'Germ-icelli', Daily Star, Dhaka, July 30, 2013, Back Page.

11 "Study on Munshiganj samples -Turmeric powder way too toxic" The Daily Star, Dhaka, November 15, 2013, Front Page.

12 "PRAN turmeric", see note 9. 
13 “Safe drinking water," Financial Express, Dhaka, September 6, 2013, Editorial.

14 "Mitford market raided-fake, foreign medicine seized," Daily Star, Dhaka, September 29, 2013, Back Page.

15 J. Ziegler, UN Special Rapporteur on the right to food, Economic, Social and Cultural Rights: The right to food, UN Doc. No. E/CN.4/2004/10 (2004), para. 22.

${ }_{17}$ Negri, see note 1, p. 16.

17 See, eg, A. M. Amin et al, "Eating away our health," Daily Star, Dhaka, November 5, 2004, Weekend Magazine, Cover Story.

${ }^{18}$ See, eg, Hasan, note 6.

${ }^{19}$ See, eg, "Adulterated chilli powder seized in Ctg," Daily Star, Dhaka, August 11, 2009, Metropolitan.

${ }^{20}$ The Survey was cited in Q. M. Ali, "Some aspects of consumer protection in Bangladesh," Dhaka University Studies Part-C (1984), p. 111.

${ }^{21}$ N. Badrie, S. Y. D. Leon and M. R. A. Talukder, "Food safety management systems: initiatives of Trinidad and Tobago, West Indies, Philippines and Bangladesh," (paper presented at Caribbean Agro-Economics Society $26^{\text {th }}$ West Indies Agricultural Economic Conference, Puerto Rico, July 2006), p. 85.

${ }^{22}$ S. M. Rahman, M. A. Hoque and M. R. A. Talukder, "Food security in Bangladesh: utilization, nutrition and food safety," (paper presented at the National Workshop on Food Security, Dhaka, Bangladesh, October 19-20, 2005) pp. 45-46.

${ }^{23} \mathrm{~J}$. Ziegler et al, The fight for the right to food: lessons learned (Palgrave Macmillan, 2011), p. 2 .

${ }^{24}$ Food and Agriculture Organization, "Nutrition Country Profile: Bangladesh-Summary" (2010). Available at http://www.fao.org/ag/agn/nutrition/bgd_en.stm.

${ }^{25}$ G. H. Brundtland, "Food safety: an essential public health issue for the new millennium," (WHO/SDE/PHE/FOS/99.4, World Health Organization, 1999), p. 2.

${ }^{26}$ Food Safety Programme, "Populations at risk." (World Health Organisation, 1999) p. 1.

Available at

http://www.who.int/foodsafety/publications/general/en/fos_brochure1999_2en.pdf.

27 See generally, Figure 1.11 at United Nations International Children's Emergency Fund (UNICEF), "The State of the World's Children 2008: Child Survival," (2007), p. 11.

${ }^{28}$ See, for details, "Speakers liken food adulteration to genocide," Financial Express (August 5, 2010), Metro/Country.

${ }^{29}$ Ibid.

30 DGHS, "Public Health Interventions by Selected Institutions," (Government of Bangladesh, November 24, 2010), p. 6.

31 NTFS, "Bangladesh country paper," (paper presented at the FAO/WHO Regional Conference on Food Safety for Asia and Pacific, Seremban, Malaysia, May 24-27, 2004), p. 6.

${ }^{32}$ Ibid.

${ }^{33}$ Ibid. The NTFS refers to the 1998 Annual Report of the International Centre for Diarrhoeal Disease Research, Bangladesh.

${ }^{34}$ DGHS (see note 30 ).

35 "Study on Munshiganj", see note 11.

${ }^{36}$ Ibid.

${ }^{37}$ Ibid.

${ }^{38}$ Ibid.

${ }^{39}$ Ibid. 
${ }^{40}$ The discussion of the weaknesses in the existing legal and regulatory regime falls beyond the scope of this article as they have been critically analysed elsewhere. See A. N. M. A. Ali, "Food safety and public health issues in Bangladesh: a regulatory concern," European Food and Feed Law Review 8/1 (2013), pp. 31-40.

${ }^{41}$ For details about enforcement of international human rights by domestic courts, see M. S. Alam, "Enforcement of International Human Rights Law by Domestic Courts: A Theoretical and Practical Study," Netherlands International Law Review 53 (2006), p. 399.

42 Cornell University Law School, "Fundamental rights" (August 19, 2010). Available at http://www.law.cornell.edu/wex/fundamental_right.

43 See M. C. Dorf, "Incidental burdens on fundamental rights," Harvard Law Review 109 (1996), p. 1176.

44302 U.S. 319, 326 (1937).

45116 US 616, 635 (1886) per Justice Bradley as quoted in W. J. Brennan, Jr., "State constitutions and the protection of individual rights," Harvard Law Review 90 (1977), p. 494.

46 (1999)19 BLD (HCD) 488.

47 (1994)14 BLD (HCD) 266.

${ }^{48}$ Alam, note 41, p. 413.

${ }^{49}$ Kiobel v Royal Dutch Petroleum, 621 F 3d 111 (2d Cir, 2010); D. Weiss and R. Shamit, "Corporate accountability to rights: the case of Gaza strip," Harvard Human Rights Journal 24 (2011), pp. 155-56.

${ }^{50}$ Office of the High Commissioner for Human Rights (OHCHR), "Fact sheet no 34 - the right to adequate food," (United Nations Human Rights, 2010), p. 31.

${ }^{51}$ JT (1997) (7) SC 392. AIR (1997) SC 3011. See also the interpretations of the right to life as a fundamental right under art 21 of the Indian Constitution by the SCI in: Chameli Singh v. State of U.P., 1996 AIR 1051, 1996(2) SCC 549.

52 (1995) 183 CLR 273.

${ }^{53}$ Ziegler et al, 2011, note 23, p. 159.

${ }^{54}$ F. Menghistu, "The satisfaction of survival requirements," in B. G. Ramcharan (ed) The Right to Life in International Law (Martinus Nijhoff Publishers, 1985), p. 63.

${ }_{55}$ Although this article focuses on 'the right to safe food' as part of international human rights, this right has been hardly explored in human rights legal scholarships: Negri, note 1, p. 3.

${ }^{56} \mathrm{OHCHR}$, note 50, p. 2.

${ }^{57}$ Ibid., p. 5.

${ }^{58}$ Ibid.

${ }^{59}$ Right to Food, GA Res 67/174, UN.GAOR, $4^{\text {th }}$ Comm, $67^{\text {th }}$ Sess, Agenda Item 69 (b), UN Doc A/RES/67/174 (3 April 2013) para. 27.

${ }^{60}$ Negri, note 1, p. 3 (citation omitted).

${ }^{61}$ Menghistu, note 54.

${ }^{62}$ UN Doc. CCPR/C/SR.222 para. 59 (1980).

63 Food and Agricultural Organization, "Trade and food security: conceptualizing the linkages," (2003), p. 27.

${ }^{64}$ See A. G., S. Armenta and M. D L. Guardia, "Adulteration detection of argan oil by inductively coupled plasma optical emission spectrometry," Food Chemistry 121 (2010), p. 878.

${ }^{65}$ Ziegler et al, 2011, note 23.

${ }^{66} \mathrm{~K}$. Kong, "The right to food for all: a right-based approach to hunger and social inequality," Suffolk Transnational Law Review 32 (2009), p. 560. 
67 A. M. N. Renzaho, "Human right to food security in refugee settings: rhetoric versus reality," Australian Journal of Human Rights 8/1 (2002), p. 45.

${ }^{68}$ For details, see Committee on Economic, Social and Cultural Rights (CESCR), General Comment 12, The right to adequate food, UN Doc. No. E/C.12/1999/5 (1999).

${ }^{69}$ Ibid., para. 1.

${ }^{70}$ Ibid., para. 4.

${ }^{71}$ Ibid., paras. 4, 14 and 25.

${ }^{72}$ Ibid., para. 8.

${ }^{73}$ Ibid., para. 14.

${ }^{74} \mathrm{OHCHR}$, note 50, p. 3.

75 Ibid.

${ }^{76}$ United Nations, GA Resolution 51/171 on food and sustainable agricultural development A/RES/51/71 86 ${ }^{\text {th }}$ plen mtg (December 16, 1996); Right to Food, GA Res 57/226, UN.GAOR, $57^{\text {th }}$ Sess, $77^{\text {th }}$ plen $m$ tg, Supp No 49, UN Doc A/RES/57/226 (February 26, 2003), p. 2.

${ }_{78}^{77}$ Human Rights Council, “The right to food,” Resolution 7/14 (March 27, 2008).

78 J. Ziegler, "Right to food: mission to Bangladesh." $16^{\text {th }}$ sess, UN Doc E/CN.4/2004/10/Add.1 (October 29, 2003), p. 9.

${ }^{79}$ Ziegler et al, 2011, note 23, p. 159.

${ }^{80}$ Ziegler, 2003, see note 78, p. 17.

${ }^{81}$ OHCHR, note 50, p. 18.

${ }^{82}$ Ibid.

83 Committee on Economic, Social, and Cultural Rights, General Comment No. 14, The Substantive Issues Arising in the Implementation of the International Covenant on Economic, Social, and Cultural Rights, UN Doc. No. E/C.12/2000/4 (2000) paras. 2 and 43.

${ }^{84}$ OHCHR, note 50, p. 18.

${ }^{85}$ Writ petition No. $1190 / 2009$, para. 23.

${ }^{86}$ (1997) 17 BLD (HCD) 577.

${ }^{87}$ (2000) 20 BLD (HCD) 341.

${ }^{88}$ CESCR, note 68.

${ }^{89}$ Farooque vs. Government of Bangladesh (1996) 48 DLR 438.

${ }^{90}$ Ibid., per Kazi Ebadul Hoque J.

${ }^{91}$ T. Pogge, "Are we violating the human rights of the world's poor?," Yale Human Rights \& Development Law Journal 14 (2011), p. 3.

${ }^{92}$ Writ Petition (Civil) No.196 of 2001. See also Centre for Public Interest Litigation vs.

Union of India Writ Petition (Civil) No. 681 of 2004.

${ }^{93}$ Committee on Social, Economic and Cultural Rights, "General Comments on No. 3: The nature of state parties' obligations," (1990), UN Doc, HRI/GEN/1/Rev 7, May 12, 2004, para. 10 .

${ }^{94}$ Human Rights Council, "Joint report of the independent expert on the question of human rights and extreme poverty, Magdalena Sepúlveda Cardona, and the independent expert on the issue of human rights obligations related to access to safe drinking water and sanitation, Catarina de Albuquerque - Mission to Bangladesh," Agenda Item 3, 15 ${ }^{\text {th }}$ sess, A/HRC/15/55, December 3-10, 2009, p. 13.

${ }^{95}$ OHCHR, note 50, p. 17.

${ }^{96}$ Ali, 2013, note 40.

97 Human Rights and Peace for Bangladesh v Bangladesh [2009], Writ Petition No. 1190/2009, Supreme Court of Bangladesh (HCD), para. 23.

98 "Food courts still stuck in red tape," Daily Star, Dhaka, November 2, 2013, Front page. 
${ }^{99}$ Ibid.

100 M. Karim, "US expresses to help Bangladesh with pure food act," Dhaka Tribune, October 9, 2013, Foreign Affairs.

${ }^{101}$ A. N. M. A. Ali, "Application of responsive regulation in the food safety regulations of Bangladesh," Journal of South Asian Studies 1/1 (2013), pp. 41-49; see also A. N. M. A. Ali, "Responsive regulation and application of grading systems in the food safety regulatory regimes of developing countries," Food Studies: An Interdisciplinary Journal 2/1 (2013), pp. $31-43$.

${ }^{102}$ Ali, 2013, note 40. 